\title{
Evaluation of the nutritional status changes of resident physicians before and during the COVID-19 Pandemic
}

\section{Asistan hekimlerde Covid-19 öncesi ve sırasında çalışma ortamında beslenme durumu değişikliğinin} saptanmasi

\author{
Nazlı Batar ${ }^{1}$, Ceren Pak ${ }^{1}$, R.Nükra Tüfekçi ${ }^{1}$, Betül Koçak ${ }^{2}$, Rümeysa Özçalkap ${ }^{1}$, Pelin Pak ${ }^{3}$, Seçil Arıca ${ }^{3}$
}

\begin{abstract}
Aim: This study was conducted to determine nutritional changes in the working environment of resident physicians before and during the coronavirus 2019 (COVID-19) pandemic.

Methods: Resident physicians working at Prof. Dr. Cemil Taşçığlu City Hospital and who agreed to participate were included in the study. Data were collected using an online questionnaire method developed by the researchers for determining demographic characteristics and nutritional changes in the study participants. Results were analyzed with the SPSS statistical program.

Results: The COVID-19 outbreak affected the nutritional status of $82.2 \%$ of the resident physicians. The rate of physicians trying to eat a healthy diet during the pandemic was $79.1 \%$. However, the number of physicians who increased their consumption of fruits and vegetables during the epidemic was $58.2 \%$. During the pandemic, water consumption of the resident physicians was evaluated, and a $51.1 \%$ decrease in water consumption was found. While $78.3 \%$ of the physicians slept 6-8 hours per night before the pandemic, this rate decreased to $56.6 \%$ during the pandemic while the number of physicians who slept for 1 to 5 hours increased to $38 \%$ during the Covid-19 outbreak. A significant relationship between sleep duration before and during the pandemic was found $(\mathrm{p}<0.05)$.

Conclusion: The Covid-19 outbreak has greatly and continues to affect the living standards of resident physicians. During the study period, it was observed that the diet and sleep patterns of resident physicians who worked in an intense environment had been disrupted.

Keywords: Covid-19, Resident physician, Healthy diet, Sleep
\end{abstract}

Öz

Amaç: Bu çalışmada, koronavirüs (COVID-19) salgını öncesi ve sırasında asistan hekimlerin çalışma ortamında beslenme durumu değişikliklerinin saptanması amacıyla yapılmıştır.

Materyal ve Metod: Prof. Dr. Cemil Taşçıŏglu Şehir Hastanesinde görev yapan ve çalışmaya katılmayı kabu eden asistan hekimler çalıșmaya dahil edilmiștir. Araștırmaya katılan bireylerin demografik özelliklerini ve beslenme durumu değişikliklerini belirlemek için araştırmacılar tarafından geliştirilen online anket yöntemi ile veriler toplanmıştır. Sonuçlar SPSS istatistik programı ile analiz edilmiştir.

Bulgular: Covid-19 salgını asistan hekimlerin \%82,2'lik kısmının beslenme durumunu etkilemiştir. Salgın sırasında sağlıklı beslenmeye çalışan hekim oranı \%79,1 olarak saptanmıştır. Bununla beraber meyve ve sebze tüketimini salgın sırasında arttıran hekim sayısı ise \%58,2'dir. Salgın sırasında asistan hekimlerin su tüketimleri sorgulanmış ve \%51,1 oranında azalma saptanmıştır. Salgın öncesi hekimlerin \%78,3'ü 6-8 saat oranında uyurken, salgın sırasında bu oran \%56,6'ya düşmüş ve 1-5 saat uyuyan hekim sayısı \%38'e çıkmıştır. Salgın öncesi ve salgın sırasında uyku süresi arasında anlamlı bir ilișki olduğu görülmüștür $(\mathrm{p}<0.05)$.

Sonuç: Covid-19 salgını asistan hekimlerin yaşam standartlarını büyük ölçüde etkilemiştir. Bu dönemde yoğun çalışma temposu içerisinde olan asistan hekimlerin beslenme ve uyku düzenlerinin bozulduğu görülmüștür.

Anahtar kelimeler: Covid-19, Asistan hekim, Sağlıklı beslenme, Uyku
${ }^{1}$ Istanbul Kültür University, Health Sciences Faculty, Department of Nutrition and Dietetics, Istanbul, Turkey.

${ }^{2}$ Atlas University, Health Sciences Faculty, Department of Nutrition and Dietetics, Istanbul, Turkey.

${ }^{3}$ Prof.Dr.Cemil Taşcıoğlu City Hospital, Department of Family Physician, Istanbul, Turkey.

iD

NB: 0000-0001-9527-5709

CP: 0000-0002-9418-6795

RNT: 0000-0002-8294-3197

BK: 0000-0003-3664-9066

RÖ: 0000-0002-8006-0411

PP: 0000-0002-0831-355X

SA: 0000-0003-0135-6909

Ethics Committee Approval: This study was approved by the Istanbul Kültür University Ethics Committee (2021.12)

Etik Kurul Onayı: Bu çalışma için Istanbul Kültür Universitesi Etik Kurulu'ndan onay alınmıştır (2021.12)

Conflict of Interest: No conflict of interest was declared by the authors.

Çıkar Çatışması: Yazar çıkar çatışması bildirmemiştir.

Financial Disclosure: The authors declared that this case has received no financial support.

Finansal Destek: Yazarlar bu çalışma için finansal destek almadıklarını beyan etmişlerdir.

Geliş Tarihi / Received: 08.04.2021

Kabul Tarihi / Accepted: 26.07.2021

Yayın Tarihi / Published: 02.08.2021

Sorumlu yazar / Corresponding author:

Nazlı Batar

Adres/Address: İstanbul Kültür University, Health Sciences Faculty, Department of Nutrition and Dietetics, E5 Karayolu Üzeri, No: 22 Bahçelievler 34191 Istanbul, Turkey.

e-mail: n.batar@iku.edu.tr

Tel/Phone: 0533-413-3717

Copyright (C) ACEM 


\section{Introduction}

In 2019, the World Health Organization's (WHO) China Country Office announced cases of pneumonia with unknown etiology and unknown mode of transmission had spread in Wuhan located in Hubei province. On January 7, 2020, this disease was defined as a new type of coronavirus (2019nCoV/COVID-19) that had not previously been seen in humans. WHO described the COVID-19 outbreak as an "international public health emergency" on January 30 after which COVID-19 cases were found in 113 countries outside of China and had spread to six continents except Antarctica. Immediately after the first positive case was seen in Turkey on March 11, 2020 and due to the rapid spread and severity of the virus, COVID-19 was defined as a global epidemic/pandemic [1].

During this pandemic, healthcare workers who work at a very intense pace had to adapt to working at this newer pace [2]. It is the responsibility of the hospital management to protect and care for healthcare professionals during this process. In one study, it was determined that a patient who came to the hospital during the pandemic could transmit the COVID-19 virus to 10 physicians in the same environment [3]. Resident physicians, who are at the forefront of the pandemic process, are at risk during this period, both physically and psychologically [4]. Multiple factors, such as the fact that the hospital in which they work is a pandemic hospital, the increase in working hours, the fact that their colleagues could be or become infected, the equipment is not sufficient, and the treatment of the disease is not certain, increase the negative psychological and physical effects of handling this crisis for these healthcare workers [5].

Healthy nutrition is defined as adequate and balanced nutrition. It has been found that individuals who are healthy and well-nourished have an increase in their quality of life and have stronger immune systems when combatting diseases. It is very important to keep the immune system as strong as possible as a precaution against COVID-19 [6]. It is recommended that employees obtain good nutrition and when necessary, take nutritional supplements, such as vitamin-mineral supplements, and prebiotics and probiotics to allow them to maintain their hectic working schedules. Although no food or beverage that prevents or treats the transmission of COVID-19 exists, healthy nutrition, physical activity, and regular sleep have proven to be supportive when combatting this virus. In this process, an accepted precaution against this virus is that people will quarantine at a distance from each other. Mood changes, such as quarantine-associated stress and depression, can increase the tendency to eat foods with high carbohydrate density. As a result, unwanted weight gain may occur with the high sugar content found in these carbohydrate foods [7]. Published by the Turkish Dietetic Association, Covid-19 nutritional guidelines were created according to the suggested Healthy Eating Plate. In each main meal of this plate, one quarter of the meal consists of vegetables, the other quarter is whole grain products, and the remaining half consists of three equal pieces of fruit, highprotein foods (such as legumes, meat, eggs, fish, chicken, oilseeds) and dairy products (such as milk, yogurt, buttermilk, cheese). In addition, COVID-19 nutritional recommendations, such as ensuring sufficient daily water consumption and adding olive oil to meals, are found in these guidelines [9].

This study was conducted to determine the nutritional changes in resident physicians before and during the COVID-19 pandemic.

\section{Material and methods}

This study is a cross-sectional study, and all 200 resident physicians working in the Prof. Dr. Cemil Taşçığlu City Hospital constitute the study population while 129 residents who agreed to participate in this study formed the study sample. The data were collected by researchers using a questionnaire created by compiling information from the literature. The questionnaire included questions about anthropometric and demographic characteristics of individuals and nutritional status changes before and during the pandemic. Due to the pandemic, the questionnaire was not applied face-to-face but was converted into an online questionnaire form and delivered to the resident physicians. Before starting this study, the institution's approval was obtained from the hospital's chief physician, and study approval was obtained from the Ministry of Health. Resident physicians were required to read and approve the informed consent form before participating in this study. This study was based on voluntary participation, and no reward was given for participating.

Ethics committee approval for this study was obtained from Istanbul Kültür University Ethics Committee (Decision number: 2021.12).

\section{Statistical analysis}

The SPSS 20 program was used for statistical analyses. In the analysis of the data, frequencies and percentages were used to describe the group according to gender, marital status, branch, and people who lived together. Average and standard deviation values were given for body mass index (BMI) in women, men, and the whole group. The effects of working during the COVID-19 pandemic on diet, efforts to eat healthy, increases in probiotic use and vitamin $\mathrm{C}$ intake, water consumption, number of meals, fruit and vegetable consumption, sleep time before the pandemic, locations for meals before and during the pandemic, and percentage analysis were evaluated. Relationships between gender and Covid-19 diagnosis, pandemic-associated effects on diet, weight changes during the pandemic, changes in water consumption, changes in the number of meals during the pandemic, efforts to eat healthy, changes in fruit and vegetable consumption, and intake of vitamins, probiotics, and vitamin $\mathrm{C}$ was examined by using the chi-square independence test. In addition, the chi-square test of independence was used for the relationship between the location for meals before and during the pandemic. A p value $<0.05$ was considered statistically significant.

\section{Results}

The study group consisted of 74 women and 55 men (57.4\% and $42.6 \%$, respectively) and a total of 129 doctors. Ninety-six $(74.4 \%)$ of the doctors were not married and 33 $(25.6 \%)$ were married. Branches consisted of emergency medicine (8), primary care (57), internal medicine (23), dermatology (3), obstetrics (4), otolaryngologist (3), neurology (1), orthopedics and traumatology (4), pediatrics (25), and plastic surgery (1). Lifestyle status of the participants included living alone (49), with their spouse/friend (29), with their spouse and children (18), with their parents (30), and with a large family (3). The mean BMI was $22.40 \pm 8.29 \mathrm{~kg} / \mathrm{m} 2$ for women, $26.01 \pm 5.24$ $\mathrm{kg} / \mathrm{m} 2$ for men, and $23.94 \pm 7.35 \mathrm{~kg} / \mathrm{m} 2$ for the whole group.

The frequency and percentages according to the variables are shown in Table 1. Accordingly, 33.3\% of the doctors were diagnosed with COVID-19. Most (82.2\%) of the participants stated that the COVID-19 pandemic affected their diet. It can be seen that $79.1 \%$ of the participants made an effort at healthy nutrition during the pandemic. The rate of those who 
stated that they increased the use of probiotics was $63.6 \%$, and the rate of those who stated that they increased their vitamin $\mathrm{C}$ intake was $75.2 \%$.

Table 1. Frequency and percentages of variables

\begin{tabular}{llccc} 
Variables & Group n(\%) & Women & Men & Total \\
\hline \multirow{2}{*}{ COVID-19 diagnosis } & Yes & $30(40.5)$ & $13(23.6)$ & $43(33.3)$ \\
& No & $44(59.5)$ & $42(76.4)$ & $86(66.7)$ \\
\multirow{2}{*}{ Affects diet } & Yes & $66(89.2)$ & $40(72.7)$ & $106(82.2)$ \\
& No & $8(10.8)$ & $15(23.3)$ & $23(17.8)$ \\
\multirow{2}{*}{ Efforts to eat healthy } & Yes & $61(82.4)$ & $41(17.6)$ & $102(79.1)$ \\
& No & $13(74.5)$ & $14(25.5)$ & $27(20.9)$ \\
\multirow{2}{*}{ Increase in probiotic intake } & Yes & $47(63.5)$ & $35(63.6)$ & $82(63.6)$ \\
& No & $27(36.5)$ & $20(36.4)$ & $47(36.4)$ \\
Increase in vitamin C intake & Yes & $59(79.7)$ & $15(69.1)$ & $97(75.2)$ \\
& No & $15(20.3)$ & $17(30.9)$ & $32(24.8)$ \\
\hline COVID-19: Coronavirus 2019 & & & &
\end{tabular}

Nutritional behavior during the epidemic is given in

Table 2. Participants stated that water consumption decreased by $55.1 \%$ during the pandemic. Similarly, $59.7 \%$ of the study doctors stated that their number of meals decreased. However, $58.2 \%$ of the participants increased their consumption of fruits and vegetables. In addition, vitamin supplement use was checked during the pandemic. The rate of doctors who took vitamin supplements during the study period was $53.3 \%$ (70), while the rate of those who did not take was $30.2 \%$ (39), and the rate of those who used vitamin supplements independent of the pandemic was $15.5 \%(20)$.

Table 2. Nutritional behavior during the pandemic

\begin{tabular}{llccc}
\multirow{2}{*}{ Variables n (\%) } & \multicolumn{4}{c}{ Water Consumption } \\
\cline { 2 - 5 } & & \multicolumn{4}{c}{ Men } & Total \\
\hline \multirow{3}{*}{ Water consumption } & Increased & $12(16.2)$ & $13(23.6)$ & $25(19.4)$ \\
& Decreased & $46(62.2)$ & $20(36,4)$ & $66(51.1)$ \\
& Unchanged & $16(21.6)$ & $22(40)$ & $38(29.5)$ \\
& Increased & $5(6.8)$ & $5(9.1)$ & $10(7.8)$ \\
Number of meals & Decreased & $44(59.4)$ & $33(60)$ & $77(59.7)$ \\
& Unchanged & $25(38.8)$ & $17(30.9)$ & $42(32.5)$ \\
Fruit and vegetable & Decreased & $4(5.4)$ & $3(5.5)$ & $7(5.4)$ \\
consumption & Unchanged & $22(29.7)$ & $25(29.5)$ & $47(36.4)$ \\
\hline
\end{tabular}

Information on sleep status before and after the epidemic is shown in Table 3 . While $78.3 \%$ of the participants slept between 6 and 8 hours before the epidemic, the rate of those who slept 6-8 hours during the pandemic was $56.6 \%$, and the rate of those who slept $1-5$ hours was $38.0 \%$.

Places to eat in the working environment before and during the pandemic are shown in Table 3 . While $67.2 \%$ of the participants ate at a restaurant or cafe before the epidemic, it was observed that $55 \%$ ate their meals at home during the study period. In addition, no significant difference between eating places in the work environment before and during the pandemic was found $(\mathrm{p}>0.05)$.

In Table 4 , it can be seen that significant relationships between gender, COVID-19 diagnosis, the effect of the pandemic on the diet, weight change during epidemic, and the change in water consumption during pandemic study period ( $\mathrm{p}<$ 0.05). The diets of female doctors changed at a higher rate than male doctors. The fact that the epidemic affected the diet of female doctors more than males may have contributed to the relationship that emerged in two variables. Less than half $(41.3 \%)$ of the female doctors in the study experienced weight loss during the pandemic. Weight loss of female doctors during the epidemic may have affected the relationship of weight loss based on gender. During the pandemic, $62.2 \%$ of female doctors reduced their water consumption. The reduction in women's water consumption may have an impact on the water consumption relationship based on gender. Although not included in the table, no relationship between gender and change in the number of meals during the pandemic, efforts to eat healthy, change in fruit and vegetable consumption, and vitamin supplement use, probiotic, and vitamin $\mathrm{C}$ consumption was found $(p>0.05)$.

Table 3. Sleep duration and places to eat from in the working environment before and during the pandemic

\begin{tabular}{llccc}
\multirow{2}{*}{ Variables } & \multicolumn{3}{c}{ Groups n (\%) } \\
\cline { 2 - 5 } Sleep duration before the & 1-5 Hours & Women & Men & Total \\
\hline pandemic & 6-8 Hours & $62(8.4)$ & $12(21.8)$ & $19(14.7)$ \\
& 9 Hours and more & $5(6.8)$ & $39(70.9)$ & $101(78.3)$ \\
Sleep duration during the & 1-5 Hours & $31(7.3)$ & $9(7)$ \\
pandemic & 6-8 Hours & $42(56.7)$ & $18(32.7)$ & $49(38)$ \\
& 9 Hours and more & $1(1.4)$ & $6(10.4)$ & $73(56.6)$ \\
Place to eat from before & Dining Hall & $24(32.9)$ & $9(16.4)$ & $73(5.4)$ \\
the pandemic & Restaurant / Cafe & $45(61.6)$ & $41(74.5)$ & $86(67.2)$ \\
\multirow{3}{*}{$\begin{array}{l}\text { Place to eat from during } \\
\text { the pandemic }\end{array}$} & From Home & $4(5.5)$ & $5(9.1)$ & $9(7)$ \\
& Dining Hall & $13(17.6)$ & $15(27.3)$ & $28(21.7)$ \\
& Restaurant / Cafe & $16(21.6)$ & $14(25.5)$ & $30(23.3)$ \\
& From Home & $45(60.8)$ & $26(47.2)$ & $71(55)$ \\
\hline
\end{tabular}

Table 4. Relationships of variables according to gender

\begin{tabular}{|c|c|c|c|c|c|c|c|}
\hline \multirow{2}{*}{ Variables } & \multirow{2}{*}{ Category } & \multicolumn{2}{|c|}{ Gender n (\%) } & \multirow{2}{*}{ Total } & \multirow{2}{*}{$\mathrm{X}^{2}$} & \multirow{2}{*}{ df } & \multirow{2}{*}{$\mathrm{p}$} \\
\hline & & Women & Men & & & & \\
\hline \multirow{2}{*}{$\begin{array}{l}\text { COVID-19 } \\
\text { diagnosis }\end{array}$} & Yes & $30(40.50)$ & $13(23.60)$ & 43(33.30) & \multirow{2}{*}{3.33} & \multirow{2}{*}{1} & \multirow{2}{*}{0.033} \\
\hline & No & $44(59.50)$ & $42(76.30)$ & $86(66.70)$ & & & \\
\hline \multirow{3}{*}{$\begin{array}{l}\text { Pandemic's } \\
\text { affect on diet }\end{array}$} & Affected & $66(89.20)$ & $40(72.70)$ & $106(82.20)$ & \multirow{3}{*}{4.77} & \multirow{3}{*}{1} & \multirow{3}{*}{0.015} \\
\hline & \multirow{2}{*}{ Not affected } & $8(10.80)$ & $15(27.30)$ & $23(17.80)$ & & & \\
\hline & & $10.80 \%$ & $27.30 \%$ & $17.80 \%$ & & & \\
\hline \multirow{3}{*}{$\begin{array}{l}\text { Weight during } \\
\text { pandemic }\end{array}$} & Increased & $23(31.10)$ & $17(30.90)$ & $40(31.00)$ & \multirow{3}{*}{6.15} & \multirow{3}{*}{2} & \multirow{3}{*}{0.046} \\
\hline & Decreased & $31(41.30)$ & $13(23.60)$ & $44(34.10)$ & & & \\
\hline & $\begin{array}{l}\text { Not } \\
\text { changed }\end{array}$ & $20(27.00)$ & $25(45.50)$ & $45(34.90)$ & & & \\
\hline \multirow{3}{*}{$\begin{array}{l}\text { Water } \\
\text { consumption } \\
\text { during } \\
\text { pandemic }\end{array}$} & Increased & $12(16.20)$ & $13(23.60)$ & $25(19.40)$ & \multirow{3}{*}{8.62} & \multirow{3}{*}{2} & \multirow{3}{*}{0.013} \\
\hline & Decreased & $46(62.20)$ & $20(36.40)$ & $66(51.20)$ & & & \\
\hline & $\begin{array}{l}\text { Not } \\
\text { changed }\end{array}$ & $16(21.60)$ & $22(40.00)$ & $38(29.50)$ & & & \\
\hline
\end{tabular}

Table 5 shows the relationship between sleeping hours before and after the pandemic started. It is observed that $78.3 \%$ of the participants slept between 6 and 8 hours daily before the pandemic. In addition, a significant relationship between preand pandemic period sleep time was found $(\mathrm{p}<0.05)$. The fact that 33 people $(67.3 \%)$ who slept for 6 to 8 hours before the epidemic only slept for 1 to 5 hours during the pandemic led to a significant change in sleep time.

Table 5. Relationship between sleep duration before and after the pandemic.

\begin{tabular}{|c|c|c|c|c|c|c|c|c|}
\hline \multirow{2}{*}{ Variables } & \multirow{2}{*}{ Category } & \multicolumn{3}{|c|}{$\begin{array}{l}\text { Sleeping duration during the } \\
\text { pandemic } \mathrm{n}(\%)\end{array}$} & \multirow{2}{*}{ Total } & \multirow{2}{*}{$X^{2}$} & \multirow{2}{*}{ df } & \multirow{2}{*}{$\mathrm{p}$} \\
\hline & & 1-5 Hours & $6-8$ Hours & $\begin{array}{c}\geq 9 \\
\text { Hours }\end{array}$ & & & & \\
\hline \multirow{3}{*}{$\begin{array}{l}\text { Sleeping } \\
\text { duration } \\
\text { before } \\
\text { the } \\
\text { pandemic }\end{array}$} & 1-5 Hours & $14(28.60)$ & $3(4.10)$ & $2(28.60)$ & 19 (14.7) & \multirow{3}{*}{30.94} & \multirow{3}{*}{4} & \multirow{3}{*}{0.000} \\
\hline & 6-8 Hours & $33(67.30)$ & $66(90.40)$ & $2(28.60)$ & 101(78.3) & & & \\
\hline & $\geq 9$ Hours & $2(4.10)$ & $4(5.50)$ & $3(42.80)$ & $9(7.00)$ & & & \\
\hline
\end{tabular}




\section{Discussion}

The aim of this study was to question and evaluate the nutritional changes of resident physicians in their work environments before and after the start of the COVID-19 pandemic. Only a limited number of studies concerning this issue can be found in the literature, and most of them are focused on the general population rather than healthcare professionals/students studying in health-related departments. For this reason, this study about healthcare professionals is important because it is one of the only studies to address this important issue. The mean BMI was $22.40 \pm 8.29 \mathrm{~kg} / \mathrm{m}^{2}$ (normal) for female resident physicians, $26.01 \pm 5.24 \mathrm{~kg} / \mathrm{m}^{2}$ (overweight) for male resident physicians, and $23.94 \pm 7.35 \mathrm{~kg} / \mathrm{m} 2$ for the whole group. It has been found based on the total body surface area (TBSA) of a population that the frequency of being obese and overweight in women was $29.7 \%$ and $41.0 \%$, respectively; in males, it was found to be $39.1 \%$ and $20.5 \%$, respectively [10]. In a study conducted by Yücel et al., $41.7 \%$ of male physicians compared to $22.2 \%$ of female physician were overweight. On the contrary, in whole society studies conducted throughout the country, it was found that female physicians were heavier than male physicians. It has been found that the proportion of overweight and obese health workers tends to be lower than in the general population. The reason for this tendency was thought to be related to the level of consciousness of healthcare workers about diet and nutrition [11]. In our study, the average BMI value of male physicians was $26.01 \%$, and that of female physicians was found to be $22.40 \%$. These results are consistent with those from other studies.

Our physicians have played and continue to play a major role in battling this pandemic [4]. Nutrition also has been shown to have an important role in epidemic-associated protection methods. In the intense work atmosphere of physicians, disruption of their nutrition can have a negative effect on their immune systems and increase their risks of contracting Covid-19. This process can have negative results on the pace of work in this health-related battle [8]. One-hundred six $(82.2 \%)$ of the physicians participating in this study stated that the COVID-19 pandemic affected their diet. It is thought that vitamin $\mathrm{C}$, known as an immune system enhancer, may be particularly protective against COVID-19 [12]. It is known that this protection is due to the antioxidant properties of vitamin $\mathrm{C}$ [6]. It has been reported that vitamin $\mathrm{C}$ supplementation is protective against viral infections as it strengthens a person's immunity. In a study conducted in China, in addition to the treatment of patients with moderate and severe COVID-19, high doses of vitamin C (10-20g/day, 8-10 hours) were administered to 50 patients and found to be successful in treating the virus[13]. In our study, the increase in vitamin $\mathrm{C}$ consumption by resident physicians during the pandemic was found to be $75.2 \%$. In addition, those who started using additional vitamin supplements during the epidemic was found to be $53.3 \%$; $58.2 \%$ of the participants were attentive to increasing fruit and vegetable consumption. The reason for the increase in vegetable/fruit consumption and vitamin supplement during the pandemic is thought to be due to immune system enhancing effects of fruits and vegetables and the COVID relationship [14]. Fruit and vegetable consumption is also very important for strengthening the immune system and ensure adequate fiber intake for the body [15]. In some studies, fruit and vegetable consumption was found to have decreased during the pandemic. Among the reasons for this decrease, a deterioration of individuals' healthy eating habits occurred with the decrease in the number of meals. According to a study by Macit, it was determined that the use of nutritional supplements increased during the COVID pandemic. In the study, it was emphasized that individuals should be informed about adequate balanced nutrition, physical activity, and nutritional supplements [16]. In the article by Coelho-Ravagnani et al., the effects of vitamins and minerals, such as zinc, selenium, and vitamins C, A, and D during the COVID-19 pandemic were described, and it was emphasized that these nutritional supplements should be used in case of food insufficiencies; however, when possible, fresh vegetables and fruits and whole grain foods should be included in the daily diet [17]. In our study, when fruit and vegetable consumption was analyzed based on gender, it was found that consumption increased by $64.9 \%$ for female physicians and $49.0 \%$ for male physicians during the pandemic study period. However, no statistically significant relationship between the increase of fruit and vegetable consumption and gender was found ( $p>0.05)$. In the study by Celorio-Sardà et al., food consumption of individuals before and during the quarantine was examined, and a decrease in alcohol consumption with a concurrent increase in fresh vegetable and fruit consumption was found [18].

Physicians working in an intense, fast-paced environment usually cannot consume the necessary amount fruit and vegetables due to working both shifts and the in-hospital environment conditions [15]. In another study, it was determined that as the quarantine period increased, emotional eating and BMI increased, while healthy eating attitudes decreased [19]. In this study, the nutritional status of physicians before and during the pandemic was examined. It has been determined that $79.1 \%$ of the physicians tried to eat healthier during the pandemic study period than before the pandemic. It is thought that physicians see this process as an opportunity to develop healthy eating habits and after considering the possible infection risks under pandemic conditions, they might make an effort to eat healthy in order to strengthen their immune systems.

In this study, it was also observed that the healthy diets of $82 \%$ physicians were affected. In a study, the diets of healthcare workers working different shifts before the pandemic was investigated in the work environment, and it was found that they mostly preferred biscuits, crackers, and chips as snacks [20]. In the study conducted by Kesgin et al. involving nurses, it was found that more than half of the individuals generally preferred easily accessible foods and beverages such as hamburgers, toast, bagels, biscuits, chocolates, colas, and ready-made fruit juices [21]. In our study, it is thought that the reason for dietary deterioration of most of the physicians during the pandemic was that they could not find the time to eat a healthy diet due to the busy work pace, rapid and easy access of unhealthy foods, and the pandemic-related effects they experienced in their daily lives. Several other studies have shown that women placed more importance on healthy eating than men [22]. In this study, a statistically significant relationship was found that the diet of female physicians was affected more than male physicians ( $\mathrm{p}<$ $0.05)$.

Probiotics, which have a positive effect on the immune system and are frequently used during this pandemic period, have also been proven to have positive effects on our health [14] It has been found that especially garlic and kefir may exert antiviral effects against viruses affecting the respiratory tract and lungs [23]. Addition of probiotic foods (Yogurt, kefir, pickle, vinegar) to our meals is among one protective measure against Covid-19. However, in some sources, it is stated that more studies are needed because there is no clear information about the protective effect of probiotics [16]. In our study, in line with this information, $63.6 \%$ increase in the use of probiotics by resident physicians was observed. It is thought that physicians consciously add probiotics to their meals as a protective measure 
against the virus, knowing the positive effects of probiotics on the immune system.

About one-third (33.3\%) of the resident physicians who participated in our study had been diagnosed with COVID-19, $40.5 \%$ of the female resident physicians and $23.6 \%$ of the male resident physicians. The reason for this difference is thought to related to the diet of women, which has been more affected by pandemic conditions than the diets of the male participants. A statistically significant relationship was found between the status of diagnosis, the diet, water consumption, and body weight change of the participants $(p<0.05)$. It is thought that sensory loss, such as taste and smell, may have been experienced by the resident physicians who have been diagnosed, and therefore has led to a decrease in the number of meals and weight loss. In another study, it was found that regardless of being diagnosed with COVID-19, individuals may skip their main meals, especially lunch, more than before the pandemic period [24]. The effect of the epidemic on the number of meals was found to have caused significant changes not only for working individuals but also in the number of meals for all individuals. In this study, the way in which the number of meals changed in resident physicians before and during the pandemic was investigated. Over half $(59.7 \%)$ of the physicians stated that the number of meals decreased among resident physicians who were involved in an intense working environment during the pandemic period. While the rate of the number of physicians who said that the number of meals increased was $7.8 \%$, those who said that they did not change their number of meals was only $32.5 \%$. The pandemic period caused a significant decrease in the number of meals of resident physicians. Although studies involving resident physicians are inadequate, when looking at other studies examining the pandemic and the number of meals, it can be seen that a great majority of the society experienced a serious decrease in the number of meals during this period. It was determined that the individuals whose number of meals increased were actually in a constant state of snacking. Considering the number of meals according to gender in this study, it was observed that the number of meals for female physicians decreased by $59 \%$, and the number of meals by male physicians decreased by $60 \%$. In another study, it was observed that the decrease in the number of meals of female physicians was greater than that of male physicians [25]. As a result of this study, a statistically significant decrease was observed in the number of meals of resident physicians regardless of gender in this intense work environment $(\mathrm{p}<0.05)$.

In a study conducted before the pandemic with healthcare professionals, water consumption was examined and found to be $7.43 \pm 3.51$ glasses per day [11]. In our study, it was found that water consumption during the pandemic decreased significantly $(62.2 \%)$, especially in female residents. The reason for this decrease is thought to be the mask used as protective equipment against the virus in the working environment in addition to the fear and anxiety that the virus may be transmitted through the working environment. In a study conducted with doctors and nurses, it was found that stress and anxiety increased in participants during the pandemic period. In addition, stress levels and sleep times were also examined, and it was found that sleep times and stress levels were inversely proportional; as the stress level increased, sleep duration decreased [26]. In a study by Celorio-Sardà et al. involving food science students and professionals, it was determined that individuals' sleep quality decreased and their working and staying awake time increased during the COVID-19 quarantine. [18]. In a study conducted with medical faculty students, it was found that the level of anxiety and stress increased during the pandemic period [27, 28]. The results of our study show that intense physical and mental stress have negatively affected the frequency of water consumption and nutritional status in the work environment during the pandemic period.

Sleep is one of the most important health factors that increases the living standards of individuals and ensures continuity of social life. During the pandemic period, changes in living conditions have caused serious changes in the sleep patterns of individuals. This study investigated how sleep patterns have been affected in resident physicians. While $78.3 \%$ of the physicians slept between 6 and 8 hours before the start of the pandemic, the rate of those who slept 6-8 hours during the study period dropped to $56.6 \%$, and the rate of those who slept 1-5 hours was $38.0 \%$. When compared to the pre-epidemic rates, it can be seen that the pandemic causes sleep problems in physicians who are in a stressful working environment. Studies show that individuals who do not work have an increase in sleep times, which is due to the prolonged period of being at home during the pandemic. In another study conducted with physicians, it was observed that the sleep times of individuals exposed to intense working conditions during the pandemic had significantly reduced and shifts in the pandemic clinic were the main reason for this decrease [29]. In this study, a significant relationship between pre- and epidemic sleep duration was found ( $\mathrm{p}<0.05$ ). We think that $67.3 \%$ of the physicians who slept for 6 to 8 hours before the epidemic slept for only 1 to 5 hours during the epidemic, which may have caused the statistically significant difference in the data. In the study of Macit and colleagues, it was proven that the shortage of sleep time causes a tendency toward malnutrition [15]. In this study, it is felt that the pandemic has led to a reduction in sleep duration of resident physicians and caused changes in nutrition and lifestyle.

In these times, eating already prepared food is quite common among working individuals. In a study conducted involving healthcare professionals, it was found that $64.2 \%$ of them ate five or more times a week outside the home [30]. In our study, the rate of eating at restaurants and cafes while working before the epidemic was $67.2 \%$, while this rate decreased to $23 \%$ during the pandemic, and the rate of resident physicians bringing meals from home increased to 55\%. Although the European Food Safety Authority (EFSA) has proven that the virus is not transmitted from food, the surfaces used for food preparation are not disinfected, so people are afraid and worried that the surfaces can act as a tool for transmitting viruses from other fomites (the object carrying the infectious disease). That is why the resident physicians started bring their own food from their homes to their working environments after paying attention to hygiene rules [30].

First, even though COVID-19 was declared a pandemic by WHO in March 2020, not enough information on this subject is available at this point. Studies are limited, and even fewer of these limited studies involve healthcare professionals. As the pandemic continues, study results may not be conclusive. Despite these limitations, our study is the first study conducted on resident physicians, and we feel that it will pave the way for future studies.

The COVID-19 outbreak is a global pandemic that is still ongoing. As in the rest of the world, very significant healthcare measures are being taken by the health committee in Turkey. Although the health measures taken are not always sufficient within the scope of combatting the pandemic, it has been observed that the biggest measure involves the hygiene rules. This global pandemic is causing more and more infections every day; and the number of confirmed cases, the number of patients requiring intensive care treatment, and the number of deaths are still increasing. Healthcare workers are the most affected by this increase. The COVID-19 outbreak has greatly 
affected and continues to affect the living standards of resident physicians. During this study period, it was observed that the diet and sleep patterns of physicians who are in an intense work environment were significantly disrupted.

\section{References}

1. Saatçi E. COVID-19 Pandemic and health professionals: Keep them alive or survive? Türk Aile Hek Derg. 2020;24:153-166.

2. Yücesan B, Özkan Ö. Evaluation of the COVID-19 Pandemic Process in Terms of Health Management. Eurasian JHS. 2020;3 (COVID-19 Special Issue):134-9.

3. Senécal X, Kozak R, Mubareka S, Salt N, Gubbay JB, Eshaghi A, et al. Diagnosis, and management of first case of covid-19 in canada: lessons applied from sars. Clin Infect Dis. 2020;71:220710 .

4. Walton M, Murray E, Christian MD. Mental health care for medical staff and affiliated healthcare workers during the covid19 pandemic. Eur Heart J Acute Cardiovasc Care. 2020;9:241-7.

5. Emiral E, Çevik ZA, Gülümser Ş. COVID-19 Pandemisi ve İntihar. ESTÜDAM Halk Sağlığı Dergisi. 2020;5(COVID-19 Özel Sayıs1):138-47.

6. Erol A. High-Dose Intravenous Vitamin C Treatment For COVID-19. Osfpreprints [Internet]. 2020 Feb [Cited 2020 July8]. Available From: https://osf.io/p7ex8/

7. Eskici G. COVID-19 Pandemia: Nutrition Recommendations for Quarantine. Anatol Clin. 2020;1(Special Issue 1) 25:1:124-9.

8. FAO. 2020. Maintaining a healthy diet during the COVID-19 pandemic. Rome.

9. Türkiye Diyetisyenler Derneği (TDD). Covid-19 hakkında beslenme önerileri [Internet], 2020 [Cited 2021 June 21]. Available From: http://www.tdd.org.tr/index.php/duyurular/69covid-19-beslenme-onerileri

10. Sağlık Bakanlığı. Türkiye'de sağlık eğitimi ve sağlık insan gücü durum raporu. 1.Baskı. Eskişehir:YÖK; 2014.

11. Yücel B. Sağlık çalışanlarının beslenme alışkanları ve beslenme bilgi düzeylerinin incelenmesi (yükseklisans tezi): Ankara: Başkent Üniversitesi. 2015.

12. Khaerunnisa $\mathrm{S}$, Kurniawan $\mathrm{H}$, Awaluddin $\mathrm{R}$, Suhartati $\mathrm{S}$, Soetjipto S. Potential inhibitor of covid-19 main protease (mpro) from several medicinal plant compounds by molecular docking study. Preprints. 2020 March 13. doi: 10.20944/preprints202003. 0226.v1.

13. Cheng R.Z. Can early and high intravenous dose of vitamin c prevent and treat coronavirus disease 2019 (Covid-19)? Med Drug Discov. 2020 Mar; 5: 100028

14. Zeng J, Wang CT, Zhang FS, et al. Effect of probiotics on the incidence of ventilator associated pneumonia in critically ill patients: a randomized controlled multicenter trial. Intensive Care Med. 2016;42:1018-28.

15. Ünal E, Özdemir A, Yüksel Kaçan C. Covid-19 Pandemisinin Hemşirelik Öğrencilerinin Beslenme ve Hijyen Alışkanlıklarına Etkisi. Uludağ Üniversitesi Tip Fakültesi Dergisi. 2020;46:30511.

16. Macit M. Covid-19 salgını sonrası yetişkin bireylerin beslenme alışkanlıklarındaki değişikliklerin değerlendirilmesi. Mersin Univ Saglık Bilim Dergisi. 2020;13:277-88.

17. Coelho-Ravagnani CF, Corgosinho FC, Sanches FZ, Prado CMM, Laviano A, Mota JF. Dietary recommendations during the COVID-19 pandemic. Nutr Rev. 2021;79:382-93.

18. Celorio-Sardà R, Comas-Basté $\mathrm{O}$, Latorre-Moratalla ML, ZerónRugerio MF, Urpi-Sarda M, Illán-Villanueva M, Farran-Codina A, et al. Effect of COVID-19 Lockdown on Dietary Habits and Lifestyle of Food Science Students and Professionals from Spain. Nutrients. 2021;13:1494.

19. Ateş Özcan B, Yeşilkaya B. Adverse Effect of Emotional Eating Developed During the COVID-19 Pandemic on Healthy Nutrition, a Vicious Circle: A cross-sectional descriptive study. Rev Esp Nutr Hum Diet. 2021; 25(Supl. 2): e1144.

20. Demir H, Elkin N, Barut A, Bayram H, Averi S. Vardiyalı çalışan sağlık personelinin uyku süresi ve beslenme durumunun değerlendirilmesi, İGUSABDER. 2017;89-107.

21. Kesgin M, Kubilay G. Özel bir hastanede çalışan hemşirelerin yaşam alışkanlıkları ve çalışma koşullarından kaynaklı sağlık sorunlarının değerlendirilmesi. Sağlık Bilimleri Fakültesi Hemşirelik Dergisi. 2011;18: 41-49.
22. Muslu M, Özçelik Ersü, D. Yeni koronavirüs (sars-cov-2/covid19) pandemisi sırasında beslenme tedavisi ve önemi. Bes Diy Der. 2020;48:73-82.

23. Mohajer Shojai T, Ghalyanchi Langeroudi A, Karimi V, Barin A, Sadri N. The effect of allium sativum (garlic) extract on infectious bronchitis virus in specific pathogen free embryonic egg. Avicenna J Phytomed. 2016;6:458-267.

24. Küçükcankurtaran $\mathrm{S}$, Özdoğan $\mathrm{Y}$. Covid-19 pandemisinin yetişkinlerin beslenme durumuna etkisi. Düzce Üniversitesi Sağlik Bilimleri Enstitüsü Dergisi. 2020 doi:10.33631/duzcesbed.754560

25. Dilber A, Dilber F, koronavirüs (covid-19) salgınının bireylerin beslenme alışkanlıkları üzerindeki etkisi: Karaman ili örneği. Journal of Tourism and Gastronomy Studies. 2020;8:2144-62.

26. Xiao H, Zhang Y, Kong D, Li S, Yang N. The effects of social support on sleep quality of medical staff treating patients with coronavirus disease 2019 (covid-19) in January and February 2020 in China. Med Sci Monit. 2020;26: E923549.

27. Sartorao Filho CI, Rodrigues WCDLV, De Castro RB, Arlete Aparecida Marçal, Shirlene Pavelqueires, Luiz Takano et al Impact of covid-19 pandemic on mental health of medical students: a cross-sectional study using gad-7 and phq-9 questionnaires. medRxiv 2020.06.24.20138925; doi: https://doi.org/10.1101/2020.06.24.20138925.

28. Yakar B, Kaygusuz T, Pirinçci E, Onalan E, Ertekin Y. Knowledge, attitude, and anxiety of medical students about the current COVID-19 outbreak in Turkey. Fam Pract Palliat Care. 2020;5:36-44.

29. Danısman D, Sahip T, Hızarcı Tavlı E. Pandemi polikliniğinde asistan olmak. Konuralp Tip Dergisi. 2020;12:388-390.

30. Sağdıç O, Kayacan S, Dertli E, Arıcı M. Gıda güvenliği açısından covid-19 etmeni sars-cov-2'nin değerlendirilmesi ve korunma yöntemleri. Avrupa Bilim Ve Teknoloji Dergisi. 2020;18:927-33. 